\title{
Fertility Control: Reproductive Desires, Kin Work, and Women's Status in \\ Contemporary India
}

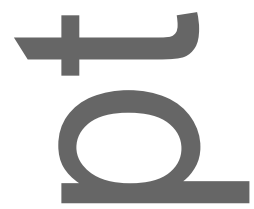

\author{
Singh, Holly Donahue ${ }^{\mathrm{a}}$
}

a Postdoctoral Fellow, Population Studies Center, Institute for Social Research, University of

Michigan 426 Thompson Street, Ann Arbor, MI 48106 USA E-mail: hd6w@virginia.edu

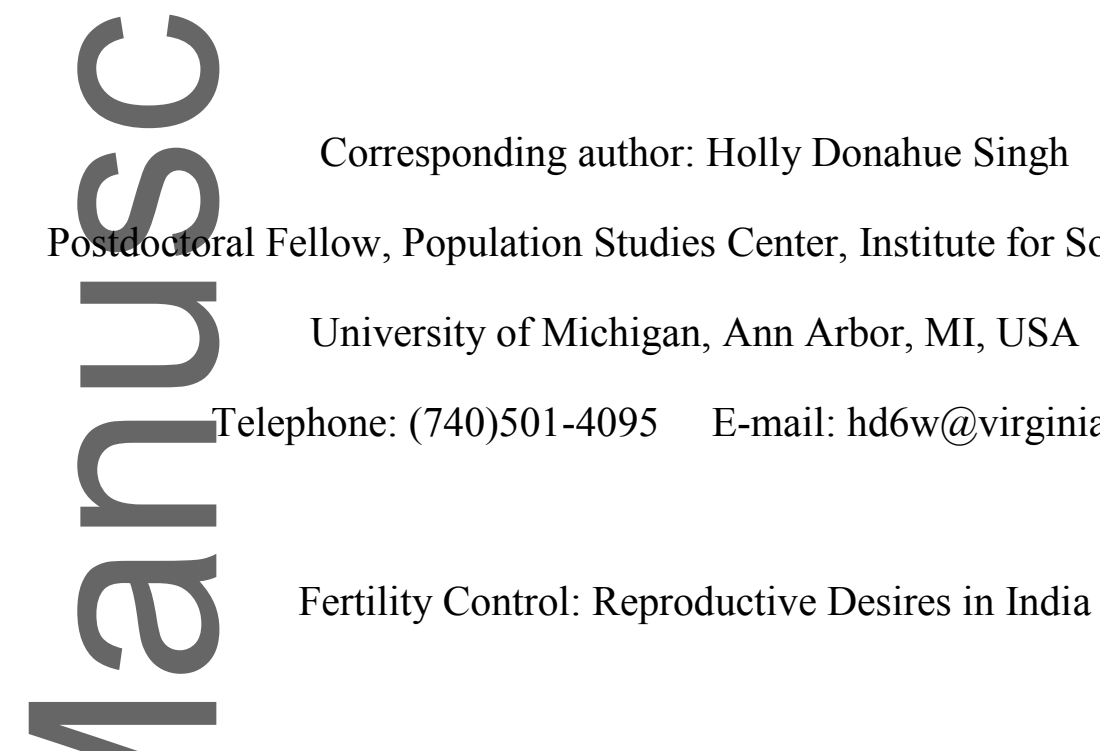

Note: An earlier, abbreviated version of this paper (2161 words, including notes and references) appears in a volume of conference proceedings, Public Health and Development in India, S.B. Nimse and M.K. Agarwal, eds. New Delhi: Northern Book Centre, 2015.

Acknowledgements: I gratefully acknowledge use of the services and facilities of the Population Studies Center at the University of Michigan, funded by NICHD Center Grant (R24 HD041028) and support from an NICHD training grant to the PSC at the University of Michigan (T32 HD007339). Colleagues in the anthropology faculty writing group at the University of Notre Dame and at the University of Michigan supported the initial writing of this article. Colleagues at Notre Dame and at the U-M PSC offered feedback. Several students provided valuable research assistance: Diana Guttierrez and Mary Schmidt at Notre Dame, and Prachi Bharadwaj and Nayna Rath at the University of Michigan . Earlier versions of the paper were presented as part of a panel, "Contested and Negotiated Lives: 'Informal' Work in North India," at the annual Madison Conference on South Asia in Madison, Wisconsin; at the conference on Public Health and Development in India at the Dr. Giri Lal Gupta Institute of Public Health at the University of Lucknow in Lucknow, India; and at Mercer University in Macon, Georgia. I am grateful for the invitations to present and especially for the comments offered by the organizers and attendees, particularly Thomas Chambers and Patricia Jeffery in Madison and M.K. Agarwal in Lucknow. Grants from the American Institute of Indian Studies and the University of Virginia supported field research.

This is the author manuscript accepted for publication and has undergone full peer review but has not been through the copyediting, typesetting, pagination and proofreading process, which may lead to differences between this version and the Version of Record. Please cite this article as doi: $\underline{10.1111 / \mathrm{maq} .12312 .}$.

This article is protected by copyright. All rights reserved. 
The field research was made possible by respondents' participation in Uttar Pradesh and by the assistance of the Department of Anthropology at the University of Lucknow.

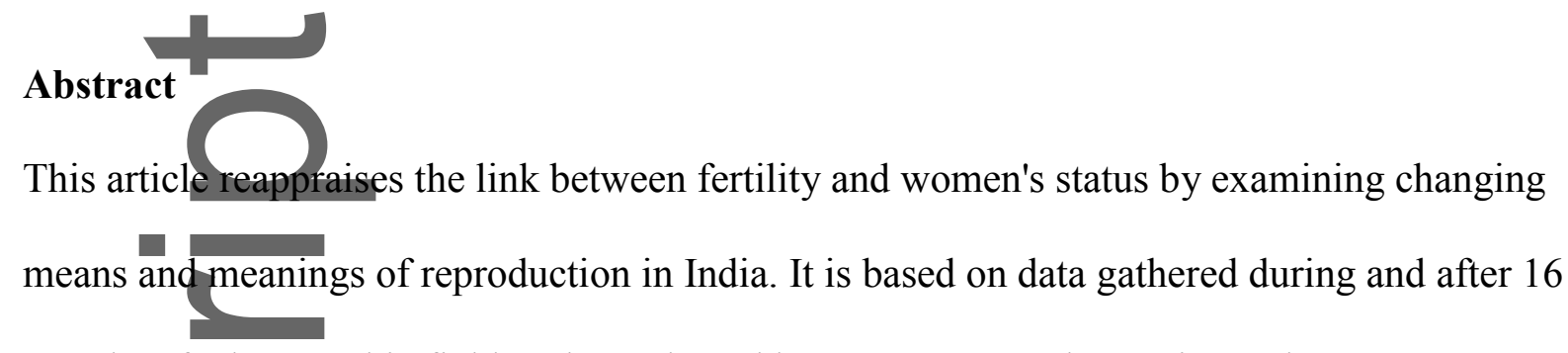
months of ethnographic fieldwork conducted between 2005 and 2007 in Lucknow, Uttar

Pradesh, India, on the social and cultural contexts of infertility. Lucknow is the capital city of Uttar Pradesh, India's most populous state. Historical views of population and fertility control in India and perspectives on the contemporary use of assisted reproductive technologies (ARTs) for practices such as surrogacy situate the ethnographic perspectives. Analysis of ARTs in practice complicates ideas of autonomy and choice in reproduction. Results show that these technologies allow women to challenge power relations within their marital families and pursue stigmatized forms of reproduction. However, they also offer new ways for families to continue and extend an old pattern of exerting control over women's reproductive potential.

\footnotetext{
Surrogacy should be seen as an opportunity to strengthen and widen our deepest ethical concerns by questioning patriarchal norms of the family and the stigmatisation of infertility. At the very least, its miraculous potential should not be used to reinforce regressive ideas about blood and inequality or rationalise it as a way to address women's economic marginalisation. (Qadeer and John 2009)

\section{Introduction}

\section{tion}

In this article, I examine fertility control by considering the ways women's bodies, and particularly women's reproductive potential, have been put into service of their marital families (in-laws) in India. I draw on fieldwork I conducted in Lucknow, Uttar Pradesh, North India, from 2005 to 2007, and on recent scholarship on surrogate pregnancy in India. Decisions about reproduction - from birth control to decisions about whether to continue a pregnancy and care of children - are undoubtedly longstanding concerns in scholarship about
} 
India, and in interventions led by a host of governmental and non-governmental organizations over the last 60 years. My work builds on long-term social science research on marriage and fertility dynamics in India (Dyson and Moore 1983; Jeffery and Jeffery 1996;Jeffery and Jeffery 1997; Jeffery et al. 1989; Patel 1994),. Here I follow scholars working on the cultural dynamics of infertility in India (Bharadwaj 2016; Mulgaonkar ** Riessman 2002; Widge 2005, 2001; Unisa 1999) to extend the discussion of infertility and infertility treatment as lenses through which to view how women do the kin work (di Leonardo 1987) of negotiating family and fertility to contribute to the reproduction of their extended marital households (sasural) under shifting cultural and economic conditions.

Even though Indian government programs and programs run by other population and reproductive health organizations have been advocating smaller families since the decade after India attained independence from British colonial rule in 1947 (Chattopadhayay-Dutt 1995), Indian families still encourage fertility, with caveats. Couples without children, or without sons, may be perceived by others as incomplete families and as insufficient contributors to extended families' long-term viability. Patterns of preference and familial pressure often influence the course of women's reproductive lives and have very real implications for their physical and social well-being. Reproductive desires relate to the sex of children, number of children, health and ability of children, and other lesser factors such as skin color. The birth of too few or too many children, especially of too many children of the "wrong"(read: female) sex, have been viewed as reproductive disruptions (Inhorn 2007) that threaten the future continuity and prosperity of patrilineal families. In North India, reproductive ideals center on families' wishes for aulad, which are biologically related children, most often imagined as male (Singh 2011). Discussions of decision-making, choice, and compulsion in Indian reproductive journeys should be read within this historical and 
social context; reproduction involves many actors and competing pulls of duty, desire, and care.

To demonstrate the context of infertility and women's status in India, I draw from my field data to examine the story of an elderly Muslim woman who recounted a particular auspicious occasion on which her long-term household labor proved to be a poor substitute for procreation in her marital home. Her account reflects larger cultural understandings of the importance of fertility and the disruptions in social relations created by infertility. I discuss the efforts of young married women in Lucknow to cultivate strong kin ties in their extended families while working towards an appearance of appropriate reproduction through the use of biomedical infertility services. I engage the emerging literature on a recent trend in India for women to attempt to secure their families' future by diverting their reproductive potential to the procreation of foreign and domestic intending parents through gamete "donation" and surrogacy (Deomampo 2013; Majumdar 2014; Pande 2014; Twine 2011; Vora 2012).

I argue that women's bodies are still put to the service of the propagation of their larger families, but not exclusively to the direct purpose of upholding patriarchal family norms by creating new [male] bodies to reproduce a patriline (vansh chalaana, literally to drive or keep descent through males going). In the process, women's body parts and their reproductive potential are being commodified. Their new bioavailability (Bharadwaj 2011; Cohen 2005) not only to their marital families, but also to domestic and transnational reproductive markets, creates ethical debates about assisted reproductive technologies, globalization, and citizenship. It also creates an opportunity to reflect anew on an "old" debate in Indiaingeneral, and Uttar Pradesh in particular, that has often been described as a social problem the link between women's fertility and their status in their marital homes (Jeffery and Jeffery 1996; Bumiller 1990). 


\section{Background}

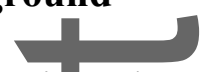

Since the early 1950s, governmental and non-governmental agencies working in India have created and implemented a host of programs intended to contain population growth by reducing the average number of births per woman. Although these programs have experiencednumerous setbacks and scandals in their planning and implementation, the national total fertility rate (TFR) in India has indeed has been reduced by about half in less than 40 years (Ram 2012), from 4.7 in 1980 (World Bank http://data.worldbank.org/indicator/SP.DYN.TFRT.IN?page=6 accessed 07/15/15) to 2.3 in 2013 (Sample Registration System Statistical Report 2013). Although these national rates reveal the overall trend in fertility, more nuanced analyses of fertility across Indian states (Dommaraju and Agadjanian 2009; Dyson and Moore 1983) and across religious, caste, and class groups (Dharmalingam and Morgan 2004; Iyer 2002; Iyer and Joshi 2013; Jeffery and Jeffery 1997) reveal a more complex picture of uneven fertility change. Both the total fertility rate and incongruity across politicized social categories have been long-standing matters of discourse and debate at local and national debate from at least the early $20^{\text {th }}$-century (Ahluwalia 2008)

While pro-natalism has a long history in India, fertility preferences and goals have shifted over time, toward fewer births, but with a continuing value on the birth of sons. Both of these dynamics are reflected in India's recent demographic history. Shrinking fertility rates, pre-natal sex-determination through technologies such as ultrasound, and continuing genderbased discrimination across the life course have exacerbated the sex ratio in recent decades, resulting in higher proportions of males relative to females, with striking variation across regions (Burke 2011; John et al 2008; Patel 2007; Unnithan-Kumar 2010; Vlassoff 2013). For example, current data indicate that for every 1000 male children born, only 909 female 
children will be born in India. In Uttar Pradesh, that number falls to 878 females per 1000 males, while other states report figures as high as 970 females per 1000 males in Chhattisgarh and as low as 864 females per 1000 males in Haryana (Sample Registration System Statistical Report 2013; see also Larsen and Kaur 2013).

These patterns persist even though Indian activists including feminists, physicians, and Hindu mationalists regularly report on and disparage such practices. Despite recent internationalattention to the biomedical infertility sector in India due to controversial practices such as transnational surrogacy (Pande 2014), and despite the significant life disruptions occasioned by infertility, relatively little is known about the numerical prevalence of infertility within India (Jejeebhoy 1998). Stigma associated with infertility discourages people from reporting fertility problems in survey research, so estimates available may well fall below reality, yet recent work suggests that infertility affects nearly 18 million couples in India (Bharadwaj 2003; Ganguly and Unisa 2010; Widge 2005). Gaps in knowledge about the prevalence of infertility and its effects persist even as, in several different guises, infertility services become part of the larger story of fertility control in reproducing families in India.

\section{Setting and Research Methods}

This article draws on data gathered through interviews, observation, and informal interactions completed by the author during 16 months of ethnographic research conducted in Lucknow, India, primarily from 2005 to 2007. Lucknow is the capital of Uttar Pradesh, the most populous state in India. With nearly 200 million people (Census India 2011 http://www.censusindia.gov.in/2011-prov-results/data_files/up/Census2011Data\%20SheetUP.pdf accessed 16 July 2015), Uttar Pradesh alone would be the fifth largest country in the world by population (Times of India 2013). Located in north-central India, it has an area of 
approximately 241,000 square kilometers (Census of India 2011). Although roughly the same size as the United Kingdom (World Bank) the state is home to more than three times as many people (United Kingdom Office for National Statistics). It holds great significance in political and cultural terms at the national level. Along with neighboring North Indian states, Uttar Pradesh often lags behind other areas of the country on a range of health indicators, including, for example, infant and maternal mortality. Recent demographic data indicates that the state's total fertility rate (TFR) continues to fall, but remains above the all-India rate. Demographic indicators from 2007 put the state's total fertility rate at 3.9 births per woman, compared to 2.7 births per woman for India as a whole (Haub 2009). The most recent statistical report from the Sample Registration System (2013) revises those numbers down to a TFR of 3.1 for Uttar Pradesh and a national rate of 2.3 (Census India SRS Statistical Reports)

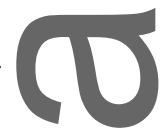

I conducted semi-structured interviews with over fifty women from a variety of religious, class, and caste backgrounds suffering from infertility. Interviews took place in government infertility clinics and outside of clinical spaces and participants were recruited opportunistically, rather than through a purposeful structured sample. Members of several local non-governmental organizations assisted with recruiting participants outside of clinics. In addition, I observed the work of 15 doctors specializing in gynecology and women's health, as well as the work of other medical staff members, with whom I conducted structured interviews and more informal interactions during clinic hours. Few potential respondents, selected on the basis of their attendance at the clinic or through reference by leaders of one of several non-governmental organizations, declined to participate. However, interview time in clinical spaces was limited by interruptions caused by scheduled procedures.

I conducted all interviews myself, drawing informally from an interview guide and allowing the conversation to take shape according to women's preferences and responses. To 
protect confidentiality, interviews with patients in infertility clinics were recorded by hand.

Other interviews were audio taped. I explained the research to each participant and obtained and documented oral consent from each participant using procedures approved by the Institutional Review Board at the University of Virgina. Interviews took place in the Hindi and Urdu vernacular language common to Uttar Pradesh, and occasionally in English, according to the preferences of participants. I am fluent in Hindi and Urdu and I have become familiar with loeal colloquial language through years of residence in Uttar Pradesh and neighboring Bihar state, so I did not work with a translator for any of the interviews. My data also come from material collected from newspapers, research produced by the Government of India, and Hindi and Urdu literature. The American Institute of Indian Studies and the University of Virginia provided provided funding for the research and provided research support, but the ultimate decisions about study design, data collection, analysis, and interpretation, and decisions about writing and publication have been mine.

I translated and analyzed field notes, audio recordings, and available documentation, and data gathered through interviews, observation, and participant-observation. Outside of biomedical infertility clinics, respondents were recruited through reference from friends, relatives, or social workers in non-governmental organizations, giving attention to including participants from diverse local backgrounds to the greatest extent possible. In biomedical infertility clinics, women presenting themselves for treatment were interviewed apart from any accompanying individuals while they waited for examination. Some interviews were conducted over several visits to the clinic for continued treatment. Medical staff in clinics provided contextual information and assisted with recruitment of participants, but staff members were generally not present during interviews. Women were informed in consent procedures that their participation was voluntary and agreeing or declining to participate in 
the research would not affect their treatment at the clinic. The vast majority of women recruited in clinics eagerly agreed to share their experiences. clinics (see Bharadwaj 2001, 2012, 2016; Widge 2001, 2005; Unisa 1999). I focus, instead, on services provided through clinics in public sector (government) hospitals, which have received less scholarly attention and have only recently begun to offer a wide range of infertility services as part of their reproductive health program, at much lower prices than in the private sector. At the time of field research, I was a doctoral candidate from the United States in my late twenties who had been married for several years to a Hindu man from Uttar Pradesh, but did not have any living children or history of pregnancy. Many women with whom I interacted asked probing questions to determine these details of my position relative to their situations, and their comments often included admonishments to try for children soon. I reflect on these dynamics and their implications for the research in more detail elsewhere (Singh 2011,2016). While important in setting the context of conversations, these dynamics did not constitute a significant barrier to field research, and may have helped to facilitate interactions. Finally, I draw on scholarly and popular media perspectives on new uses of assisted reproductive technologies in India to analyze continuity and change in the ways that women's bodies are used to reproduce their marital households.

Findings

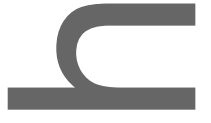

Several key themes emerged through my research. First and foremost, women's fertility matters beyond the level of the individual, and beyond the level of a couple - here, generally a married couple - with implications that ripple out to the extended family, whether or not they reside together. New daughters-in-law living in joint families in North India commonly become a primary source of domestic labor within their marital households, with 
the expectation that the distribution of labor will shift with time, and with the birth of children, both of which common sense in North Indian kinship say tend to raise a daughterin-law's status and establish her as a member of her extended marital household. But what happens when fertility problems delay the arrival of children? And how do technological innovations promote the diversion of women's reproductive potential from producing children to secure their extended family's future to generating cash for the household? Compensating for Infertility with Kin Work and Household Labor

I begin to answer these questions with the story of an elderly Muslim woman I have given the pseudonym Qudsia baji. Baji is a general term in Urdu that means "sister" or "elder sister," and is often used as a term of respect. Qudsia baji is an elderly woman I first met in 2007 through my attendance at the meetings of a ladies' organization in Lucknow. Her main focus in recalling her experiences was not on any medical or ritual intervention, but on relationships with other members of her in-laws' home. Qudsia baji recounted her contributions to running her in-laws' home in the early years of her marriage, but focused on specific occasions when she was hurt by the devaluing of her household labor through reference to her fertility status.

According to Qudsia baji, within two years of her marriage without giving birth to a child, people in her in-laws' home, her sasural, started to talk. In her narration of her reproductive history, she lived for a total of twelve years without giving birth. Then Qudsia baji became pregnant and gave birth to a baby that she believed was stillborn, but later found out had actually lived for several minutes after being born. Another six years passed before she gave birth to a son, who lived. When we spoke in 2007 , he was about twenty-one years old. In the midst of these reproductive travails, she tried at least a couple of times, unsuccessfully, to adopt a child from within her extended family. In our conversations, Qudsia baji presented herself as a person who worked hard to maintain herself and to help 
others, even though they often forgot her when she found herself in need of help. She focused on the difficulties she encountered after marriage and before children through problems with her in-laws, especially her mother-in-law (saas), her husband's sister (nand), and her husband's younger brother's wife (devrani). Although she criticized her husband for his behavior with the other members of his family, and particularly his failure, from her perspective, to vocally take issue with the treatment she received from others, she emphasized that he did not abuse her because of their childless state. Instead, he offered her comfort in private. She explained,

He [husband] never said, "we don't have any children" or, "I'll leave you".... One day my mother-in-law took him aside and said to him, "leave her.... I'll get you married again...." His habit is such that he never says anything to anyone, even now he doesn't say anything against his elders... he only argues with me... he couldn't even say to his mother, "what are you saying?" So I began to get worried. Then he said, "Why are you getting so worried? There's nothing like that, that I will leave you or get married a second time. Let her say what she wants... there are children in the family...." I never had any complaints about him, but I did from every other direction.... My methods, my manners, my getting up and sitting down... in everything, objections were my manners, my getting up and sitting down...
raised against me, but he never said anything.

While criticizing her husband for his silence, Qudsia baji also emphasized that she also remained silent, tolerating slights and criticisms by her husband's relatives. However, she remembered one particular incident that drew attention to her childless state in a way that hurt her more than the daily nitpicking that seems to have been a main feature of her interactions with her in-laws. It happened on the occasion of her husband's elder brother's daughter's (jeth: husband's elder brother; jeth ki laRki: his daughter) wedding. She contributed significant labor to the preparations for the wedding, including sewing, cooking, and preparing the house. She explained that she took a major role in getting everything ready for the wedding, and no one was concerned that her participation would have any negative impact on the girl who was to be married. She said,

I didn't confront anything, I endured it... What can I call myself.... I bore it myself... The clothes worn at the time of the nikah [Muslim marriage 
ceremony] are considered to be the most important.... I sewed all of her clothes, all of that girl's clothes... at that time, I wasn't a barren woman $[$ banjh]... putting away, picking up all of the food and supplies...

At the time of the marriage ceremony, when the bride was being dressed and prepared with special bridal jewelry, the wife of her husband's elder brother-her jethani-singled her out, and asked her not to help the bride wear the large circular nosering (nath) that is a customary part of bridal attire. At a time when women offer blessings to a new bride by assisting with her final wedding preparations, Qudsia baji's jethani put the stigma of infertility front and center, saying that this girl should not get the kind of married life that Qudsia baji had received. After all of the work she had done to prepare the household for the whole event, and even though many years had passed since the incident, she still clearly felt bitterness about her jethani's words, saying,

But at the time of the nikah I became a barren woman [banjh] So, the girl didn't wear any silver jewelry placed by my hand... so I got up and left that place. Then the whole matter got spread around the household. Shaqib's wife has gone...now Shaqib's wife has gone, so all to work has come to a standstill....

Without a child of her own, Qudsia baji took on responsibility for caring for other members of the extended household. In the course of daily life, her labor counted. She had carved out a space for herself in the everyday operation of the household. Being snubbed on such a joyous occasion both stung her pride and highlighted the complex and delicate nature of relationships within the sasural, particularly among the women living together there. The jethani's behavior on this auspicious occasion highlighted the limits of Qudsia baji's claims to reap the kinship benefits of her labor. Her experiences as a woman living with infertility in a joint family did not seem to lead her to question patriarchal family norms (Qadeer and John 2009), but to continue to seek ways to fulfill those expectations. Despite the insults, she stayed with the family and continued to cultivate strong ties within it. After many years, she finally succeeded in bringing a son of her own into the family. 
During the time of Qudsia baji's struggles over labor and procreation, the technological options for dealing with infertility, pregnancy loss, and other fertility woes were limited - it was a time when there was no in vitro fertilization anywhere in the world. Still, strategies involving shrines, holy people, plural marriage (the much-maligned co-wife), and adoption-like forms of child circulation could have brought children into her family. However, many of these strategies have low social acceptance in India, and family law limits some of them adoption and plural marriage in particular - to members of some, but not all, religious groups (Vatuk 2009; Williams 2006). For example, Muslim men, but not women, and neither men nor women of any other religious group, have been permitted to contract up to four legal marriages at a time. Until recently, only Hindus have been able to legally adopt children, although laws allowed others to become legal guardians to children (Bhargava 2005). The dynamics of fertility enhancement have undergone rapid transformation in the last few decades, with technological development, as well as reform in health care delivery. In Lucknow in 2007, many women I met in government infertility clinics came there through the help of others in their households who took responsibility for managing daily chores while they visited the clinic alone, or, most often, with their husbands. Relief from domestic duties required the cultivation of good relations within the household and presented the opportunity for women to interact with their husbands conversationally and to collaborate privately in decision-making in ways otherwise not guaranteed in joint family living arrangements.

Here, the reproductive labor carried out by daughters-in-law - in the dual sense of the Hindi/Urdu word kaam - physical workand sexual intimacy - could both move outside of the marital home. The daughter-in-law's household responsibilities, such as preparing and serving food and cleaning or supervising hired helpers, could be redistributed to another 
member of the household - a sister-in-law, an unmarried daughter of the family, the motherin-law, and/or a paid domestic worker - in order to facilitate her absence to visit the clinic. Clinical treatment could require negotiating sexual intimacy in a different location, but it could also-involve sperm "collection" in a laboratory space, or a location near the hospital, for use in intrauterine insemination (IUI) or other procedures. In some cases, the "work" of procreation took place in the hospital, with the assistance of doctors, lab technicians, and syringes. However, it also required significant effort to travel to the clinic, to procure and take the prescribed drugs, and to manage relationships necessary to facilitate ongoing financial and emotional support for infertility treatment. Procreative labor is usually not only relegated to the informal sector, but rendered invisible by codes of shame and modesty or the cover of a joke. Here, working for conception requires not only time, effort, and bodies, but also money. Procedures carried out in public hospitals cost less than they would in private hospitals. Nevertheless, treatment could require the equivalent of thousands of dollars, depending upon the diagnosis.

For many women I encountered in biomedical infertility clinics - the ones who made it there and were actively engaged in seeking children - their dedication to working towards getting children through infertility treatment helped to strengthen bonds with their husbands. Women reported that developing close bonds with their husbands did not hinge on diagnosis of male, female, or a combination of male and female factor infertility.Although some women referenced conflicts within their extended families, and insinuations by mothers-inlaw, especially, that her son could easily get remarried, women in clinics more often pointed out the strong ties that helped them pursue treatment. Emotional arguments about the affective relationships between people and the necessity of children went beyond personal desires to experience pregnancy or motherhood, and beyond childbearing as a means of creating or salvaging a husband-wife bond. For example, Gunja, whose husband was working 
in the Persian Gulf, and only periodically came to visit his wife in India, felt that she had learned much about the value of children from her own experiences. She had been married while she was still completing her bachelor's degree, and she and her husband had used birth control during the first three years of their marriage. She contrasted that time, when they were always anxious that her period not be delayed, to the present, when they wished it would not arrive. She said that her own mother had passed away after her marriage, while waiting to become a grandmother (naani), and her father-in-law had also passed away. She argued that her child would be a king (raja, implies son) in both her natal home (maike) and her in-laws' home (susraal). She said, "The child is not for my happiness, it's for the happiness of others. It will certainly bring a smile to my face, but it will also bring a smile to everyone else's face as well."

While the absence of children, or an otherwise perceived lack of a "complete" family, could prove a threat to marital stability, laboring to achieve a semblance of appropriate reproduction (which might involve innovations such as sperm donation, kept under wraps) presented a different kind of opportunity for daughters-in-law to prove their dedication to their marital families and build relationships that could prove useful in the long run, whether or not their fertility endeavors were ultimately successful. A Hindu woman named Manju, the mother of an eight-year-old daughter, came to the clinic in hopes of achieving conception, and particularly with the stated hope of getting a son. Originally from Kanpur, an industrial city about fifty miles away from Lucknow, Manju emphasized that her mother-in-law was very good, and would send her for treatment even when she didn't feel like coming to the clinic, while her father-in-law bore the cost of treatment without complaint. Despite the strong role her in-laws played in her treatment, this woman focused on her eight-year-old daughter as the main force behind her treatment, saying that she would like to have a brother for her daughter, so that she would be able to tie a rakhi (an ornamented string bracelet) on 
someone on holidays like Raksha Bandhan, a day that focuses on the special protective relationship between brothers and sisters (Singh 2014).

Women lived in the midst of lore about the fates of childless women - that they died, disappeared, or were divorced, abandoned, attacked, and/or murdered by their husbands or other relatives (Patel 1994; Times of India 2007). Although a few women questioned the alleged benefits to be reaped by having children, especially in the forms of old-age economic and emotional support and companionship (Lamb 2000; Vlassoff 1990), when weighed against the difficulties of bearing and raising them, these voices stood out as unusual among the women I spoke with in clinics. Trips to the clinic and the collaborative goal of overcoming infertility provided husbands and wives with an unusual opportunity — at least for those living in joint families - to get to know one another outside of domestic spaces and beyond the gaze of other members of the household. Strong ties generated through successfully negotiating their reproductive journeys offered women suffering from infertility in its various local forms, whether the absence of children in general or sons in particular, a glimmer of possibility for successful married life, even without achieving locally defined reproductive success.

\section{Discussion: Infertility Services Advance the Commodification of Reproductive Potential}

Women in Lucknow from many different backgrounds and with a variety of reproductive histories claimed the experience of infertility to be a source of significant suffering, but one undifferentiated by expected social divisions of class, caste, and religion. In general conversations about my research project that exceeded the boundaries of my formal, structured, clinical interactions, I heard again and again that women with infertility problems would go anywhere and do anything to get children, including, for example, visiting shrines of holy persons across religious boundaries. In this sense, women asserted 
infertility to be a unified and potentially unifying experience for women, despite significant divisions in other areas of social life.

However, research pointed to stratification of women's experiences based on different social, religious, and professional positions. These positions and the finance and relative prestige and power associated with them (or lack thereof), influenced the potential options realistically accessible to them. Commercial options in contemporary India provide new opportunities for women to fulfill or subvert familial expectations, by enhancing, reducing, or diverting their fertility. Expectations to influence, and potentially to control, women's fertility are not new features of North Indian extended families, but the means to do so and the results of those expectations are shifting with changes in the Indian economy and with technological developments in reproductive technologies that are now proliferating across India.

Whether intended to supplement a husband's earnings or secure his medical treatment, to save money for children's future school or marriages, or to improve the family's housing, women emphasize their earnings as a resource for the wider family, not for themselves. As Maya Unnithan puts it, with reference to her research on infertility in Rajasthan, western India, wornen's reproductive potential serves larger collective interests, while the particular form depends upon circumstances (Unnithan 2013:302). In other words, their bodies may be engaged for reproducing the patriarchal family, ideally by bringing forth sons to carry on the family line and to procure material wealth. But their bodies may now be more directly put to the service of creating value through gamete donation or surrogacy. Whether this redistribution of reproductive resources amounts to a threat to a highly valued ideal of motherhood (DasGupta and Das DasGupta 2010), or a clever "cure" for both poverty and perceived overpopulation in India, or an opportunity to question patriarchal family norms (Qadeer and John 2009), commercial surrogacy and gamete donation force reconsideration of the value of reproductive labor. In her recent book, Wombs in Labor, Amrita Pande (2014) 
drives this point home through the stories of surrogates at the clinic she calls Armaan in Gujarat, western India. She cites several cases of surrogates at Armaan who had aborted their own pregnancies to pursue surrogacy, delayed their own pregnancies to "save" their bodies for surrogate pregnancies, or thought that their bodies would be unable to sustain another pregnancyafter the strain of surrogacy (Pande 2014:112-116), yet mourned the necessity of these trade-offs. Despite these sacrifices, few women who worked as surrogates were able to escape poverty over the course of several years (Pande 2014:194). Surrogates' kin work, or "kin labor, "in/Pande's formulation (2014:144) involves not only engaging family members for support and domestic labor, but also evading or deceiving some relatives to pursue surrogacy's financial benefits.

Women seeking treatment of their own infertility in Lucknow clinics engaged in practices of selective concealing and revealing to pursue their reproductive aspirations, such as secretly pursuing treatments that transgress ideals of reproducing the patriline (vansh). For example, some women underwent intrauterine insemination with donor sperm (IUI-D), with formal consent from their partners. This method did not require disclosure to other family members and could be easily hidden from other family members they might fear would object, even while women enlisted their help to facilitate infertility treatment in general, in the name of the larger goal of ensuring successful reproduction. Strategies relating to the disclosure or non-disclosure of the details of infertility treatment are not evidence of liberation or autonomy in any straightforward sense. They were deeply enmeshed with the structures of everyday life, the desires of partners and members of the extended family, with women's own aspirations. As with the surrogates in the studies by Deomampo (2013) and Pande (2014), Largue that pure victimhood does not represent infertile women in my study well, yet when contextualizing their actions within the familial, local, and national worlds 
they inhabit, neither does pure independence in decision-making about the use of infertility services, including assisted reproductive technologies.

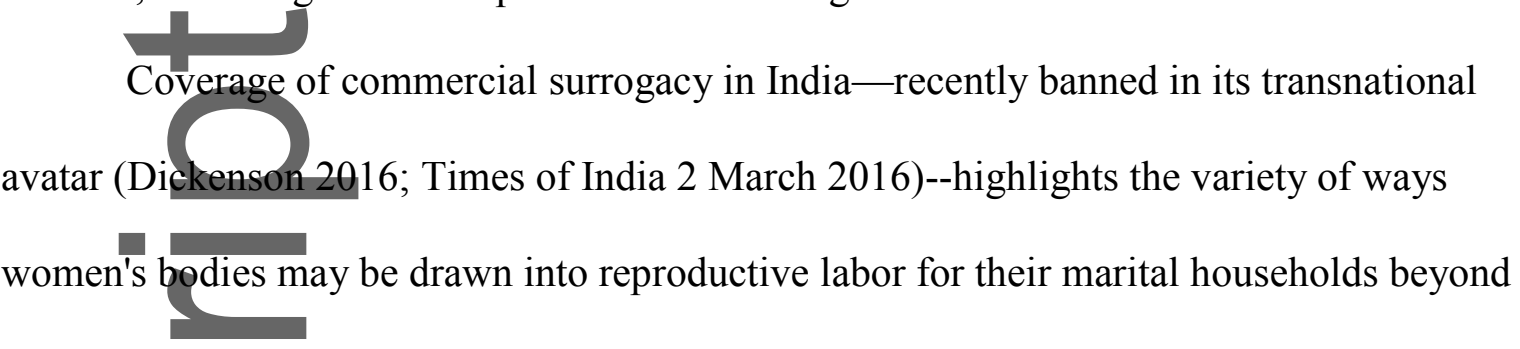
the production of progeny, or aulad, and especially male heirs. Although women's reproductive labor generally can be said to have high ideological value, within certain limits, in a variety of Indian contexts, that high ideological value does not necessarily translate into high value attributed to the women who perform such labor. A variety of measures of women's health status support that observation. The examples I have given here demonstrate how the absence of fertility raises awareness of its importance-for women who would be mothers and for others invested in their ability to produce children - because fertility, and children, cannot be taken for granted. In surrogates' negotiations, I find not only assertion of agency and slippage of the border among ideas of decision, choice, and compulsion (majburi) that raises complex ethical questions (Bailey 2011), but also women's creativity in navigating sometimes through, sometimes around, family relationships to exert some measure of reproductive autonomy, even if it means extracting value from their own bodies.

Detailed consideration of how factors of class, caste, and religion influence the particular form of fertility control, and, for example, who is most or least likely to become a surrogate or to be able to finance infertility treatment in conditions of stratified reproduction (Colen 1995) is a limitation of this article addressed in part by a larger project (Singh 2011; Singh in prep). The work presented here demonstrates that control of women's fertility has strong historical, structural, and cultural roots in North India, and that new reproductive technologies are transforming fertility control, but not unambiguously toward women's autonomy in reproduction. There is still pressure to pursue procreation, and particularly sons, 
but that pressure is entertwined with aspirations fostered by economic reform (Chua 2014), but which remain out of reach for many.

\section{Conclusion}

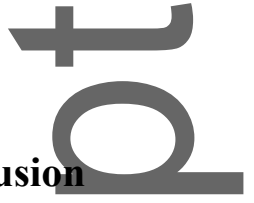

What does it mean to consider potential birthing women, whether or not they are potential mothers-to-be - that is, whether they are meant to contribute the babies they produce to their marital families or to hand them over to commissioning parents - as workers, and their reproductive bodies as objects of control by families, and sometimes by medical institutions or strangers, from which they may extract children, gametes, and ultimately, economic value? That women often labor in 'informal' and invisible spaces, which makes them vulnerable to exploitation in various forms of reproductive labor, whether in domestic labor, kin work, care work, or intimate labors of procreation, should not come as a surprise. Indeed, it is a long-term global, but also shifting, trend (Boris and Parreñas 2010; Ehrenreich and Hochschild 2002).

In the case of India, the ways that women do emotional and reproductive labor for their families, with the aid of biomedicine and biotechnology, are changing with expectations for cash and forcontrol over women's bodies, and particularly over a variety of aspects of their reproductive potential. The use of biomedical technologies enables a simultaneous focus on women's bodies as sources of both reproductive power and value, and away from their bodies as exclusively vessels for the vansh (patriline), or creators of aulad ("progeny") for their inlaws. Infertility brings diverse women together in chains of care, not necessarily of love (Meerman et al. 2001). While they connect through their intimate bodily labors, these connections tend to exacerbate, rather than alleviate, hierarchical relationships The concentration of infertility services primarily in costly private clinics in urban areas creates issues of accessibility to treatment and potential not only to begin, but also to continue 
treatment,, ultimately contributing to a largely unrecognized aspect of stratified reproduction (Colen 1995). Future research ought to highlight the inequalities and ethical complexities not only in transnational reproductive transfers, of which transnational surrogacy in India has become a prime example, but also in domestic reproduction. While technologies promise liberation and agency, at present they also offer a fair measure of majburi (compulsion) in reproduction, including ever-increasing pressure for women to acquiesce to demands upon their bodies, whether or not those demands align with their own desires for children, cash, or kin.

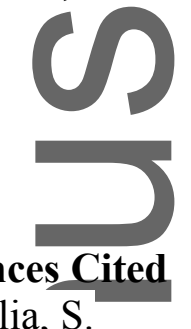

2008 Reproductive Restraints: Birth Control in India, 1877-1947. Urbana: University of Illinois Press.

Bailey, A.

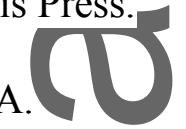

2011 Reconceiving Surrogacy: Toward a Reproductive Justice Account of Indian Surrogacy. Hypatia

Bharadwaj, A. 26(4):715-741.

2001 Conceptions: An Exploration of Infertility and Assisted Conception in India. Ph.D. dissertation,

Sociology, University of Bristol (UK).

2003. Why Adoption is Not an Option in India: The Visibility of Infertility, the Secrecy of Donor

Insemination, and Other Cultural Complexities. Social Science and Medicine 56(9):1867-1880.

2011 Reproductive Viability and the State: Embryonic Stem Cell Research in India.

In Reproduction,

Globalization, and the State: New Theoretical and Ethnographic Perspectives.

Carole-H. Browner and

Carolyn F. Sargent, eds. Pp. 113-125. Durham: Duke University Press.

2012 The Other Mother: Supplementary Wombs and the Surrogate State in India. In

Reproductive Technologies as Global Form: Ethnographies of Knowledge, Practices, and

Transnational Encounters. Michi Knecht, Maren Klotz, and Stefan Beck, eds. Pp. 139-160. Chicago: Chicago University Press.

2016 Conceptions: Infertility and Procreative Technologies in India. New York:

Berghahn.

Bhargava, V.

2005 Adoption in India: Policies and Experiences. New Delhi: SAGE Publications. Boris, E., and R. Salazar Parreñas, eds. 
2010 Intimate Labors: Cultures, Technologies, and the Politics of Care. Stanford: Stanford Social

Bumiller

Sciences.

1990 May You be the Mother of a Hundred Sons: A Journey among the Women of

India. New York:

Burke, J
Random House.

2011 Census Reveals that $17 \%$ of the World is Indian: Country Closing Gap with China by Adding

http://www.guardian.co.uk/world/2011/mar/31/census-17-percent-world-indian

Accessed 30

January 2015.

Census of India 2011

What is Total Area of Uttar Pradesh? http:/www.census2011.co.in/questions/1/statearea/total-area-of-uttar-pradesh-census-2011.html (accessed 8 December 2014)

Census of India 2011

http://www.censusindia.gov.in/2011-prov -

results/data files/up/Census2011Data\%20Sheet-UP.pdf

(accessed 16 July 2015).

Chattopadhayay-Dutt, P.

1995 Loops and Roots: The Conflict Between Official and Traditional Family

Planning in India. New

Delhi: Ashish Pub. House.

Chua, Jocelyn Eim

2014 In Pursuit of the Good Life: Aspiration and Suicide in Globalizing South India.

Berkeley:

Cohen, L.

University of California Press.

2005 Operability, Bioavailability, and Exception. In Global Assemblages:

Technology,

Politics, and Ethics as Anthropological Problems. Aihwa Ong and Stephen J.

Collier, eds., p. 79-90.

Colen, $\mathrm{S}$.

oxford: Blackwell.

Workers

1995 "Like a Mother to Them": Stratified Reproduction and West Indian Childcare

Politics of

and Employers in New York. In Conceiving the New World Order: The Global

Reprochuction. Faye D. Ginsburg and Rayna Rapp, eds. P. 78-102. Berkeley:

University of California

Press.

DasGupta, S., and S. Das DasGupta

2010 Motherhood Jeopardized: Reproductive Technologies in Indian Communities. In

The Globalization of Motherhood: Deconstructions and Reconstructions of

Biology and Care, edited by W. Chavkin and J. Maher. New York: Routledge.

Deomampo, D. 
2013 Transnational Surrogacy in India: Interrogating Power and Women's Agency. Frontiers 34(3):

$167-188,257$.

Dharmalingam, A., and Morgan, S. P.

2004 Pervasive Muslim-Hindu fertility differences in India. Demography 41(3):529545.

Dickenson, Donna

https://www.project-

2016 The End of Cross-Border Surrogacy? Project Syndicate 26 February.

syndicate.org/commentary/crackdown-on-international-surrogacy-trade-by-donnadickenson-2016-02

Accessed 19 April 2016.

Di Leonardo, M.

Kinship. Signs

1987 The Female World of Cards and Holidays: Women, Families, and the Work of

Dommaraju, P., and V. Agadjanian

2009 India's North-South Divide and Theories of Fertility Change. Journal of

Population Research

Dyson, T., and M. Moore

26(3):249-272. doi: 10.1007/s12546-009-9014-5

1983 On Kinship Structure, Female Autonomy, and Demographic Behavior in India.

Population and

Development Review 9(1):35-60. doi: 10.2307/1972894

Ehrenreich, B., and A. Russell Hochschild, eds.

2002 Global Woman: Nannies, Maids, and Sex Workers in the New Economy. New York: Henry Holt.

Ganguly, S., and Unisa, S.

2010 Trends of Infertility and Childlessness in India: Findings from NFHS

Data. Facts, Views and

Haub, C.

Vision in ObGyn 2(2):131-138.

2009 http://www.un.org/esa/population/meetings/EGM-Fertility2009/Haub.pdf.

Accessed 15 July

2015.

Inhorn, M. C.

2007 Reproductive Disruptions: Gender, Technology, and Biopolitics in the New

Millennium. New

Iyer, $\mathrm{S}$.

York: Berghahn Books.

2002 Demography and Religion in India. New Delhi: Oxford University Press.

Iyer, S., and S. Joshi

2013 Missing Women and India's Religious Demography. Journal of South Asian

Development

8(3):301-331.

Jeffery, P., and R. Jeffery

1996 Don't Marry Me to a Plowman! : Women's Everyday Lives In Rural North India.

Boulder, Colo.:

Westview Press.

Jeffery, P., Roger Jeffery, and Andrew Lyon

This article is protected by copyright. All rights reserved. 
1989 Labour Pains and Labour Power: Women and Childbearing in India. New Jersey: Zed Books.

Jeffery, R., and P. Jeffery

1997 Population, Gender and Politics: Demographic Change in Rural North India.

New York:

Jejeebhoy,

Cambridge University Press.

\section{Science Research.}

1998 Infertility in India - Levels, Patterns, and Consequences: Priorities for Social

The Journal of Family Welfare 44(2):15-24.

John, M. E.,ActionAid, and International Development Research

2008 Planning Families, Planning Gender: The Adverse Child Sex Ratio in Selected

Districts of Madhya

Pradesh, Rajasthan, Himachal Pradesh, Haryana, and Punjab. New Delhi:

ActionAid: International Development Research Centre, South Asia Regional

Lamb, Sarah

Office.

2000 White Saris and Sweet Mangoes: Aging, Gender, and Body in North India.

Berkeley: University of California Press.

Larsen, $M-$, and R, Kaur

2013 Signs of Change? Sex Ratio Imbalance and Shifting Social Practices in Northern

India. Economic

Majumdar, A

\& Political Weekly 31 August, p. 45-52.

2014 Nurturing an Alien Pregnancy: Surrogate Mothers, Intended Parents and

Disembodied

Relationships. Indian Journal of Gender Studies 21(2):199-224.

Meerman, M., A. Oey, F. Van Saane, F. Smal, \& First Run/Icarus

2001 Keten van liefde chain of love. Chain of love. Brooklyn, N.Y.: [Distributed by]

First Run/Icarus

Films.

Mulgaonkar, V.B.

2001 Childless Couples in the Slums of Mumbai: An Interdisciplinary Study. Asia-

Pacific Population

Pande, A

$$
\text { Journal 16(2):141-160. }
$$

2014 Wombs in Labor: Transnational Commercial Surrogacy in India. New York:

Columbia University

Patel, T.

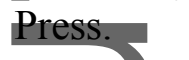

1994 Fertility Behavior: Population and Society in a Rajasthan Village. Delhi: Oxford University Press.

2007 Sex-selective Abortion in India: Gender, Society and New Reproductive

Technologies. New Delhi:

Sage Publications.

Qadeer, I., and M. E. John

2009 The Business and Ethics of Surrogacy. Economic and Political Weekly January 10, p. 10-12.

Ram, B. 
2012 Fertility Decline and Family Change in India: A Demographic

Perspective. Journal of Comparative

Family Studies 43(1):11-40.

Riessman, C. K.

2002 Positioning Gender Identity in Narratives of Infertility: South Indian Women's Lives in Context.

In Infertility Around the Globe: New Thinking on Childlessness, Gender, and Reproduction, edited

by Marcia C. Inhorn and Frank van Balen, p. 152-170. Berkeley (CA): University of California Press.

Sample Registration System Statistical Report 2013.

July 2015

http://www.censusindia.gov.in/vital_statistics/SRS_Reports_2013.html accessed 15

Singh, D.

$2014 \mathrm{I}$ 'm Supposed to be my Sister's Keeper, but She's the One Who Looks After Me PRI's The World http://www.pri.org/stories/2014-08-07/im-supposed-be-mysisters-keeper-shes-onewho-looks-after-me accessed 29 April 2016.

Singh, $\mathrm{H}$.

In prep Infertility in a Crowded Country: Hiding Reproduction in India. Book manuscript under review.

201 Aulad: Infertility and the Meanings of Children in North India. Ph.D.

dissertation, Department of

Anthropology, University of Virginia.

In press [2016] Patriarchy, Privilege, and Power: Intimacies and Bargains in

Ethnographic Production.

Anthropology and Humanism 41(1).

Times of India, Delhi edition

2016 New Bill to 'Settle' Surrogacy Issues.

http://timesofindia.indiatimes.com/india/New-bill-to-settle-surrogacy-

issues/articleshow/51218061.cms. 2 March. Accessed 20 April 2016.

Times of India, Lacknow edition

2007 Times News Network. August 2, p. 6.

2013 UP to Trigger Explosion: State's Population May Rise to 28 Crore by 2028. 15

June.

Twine, $\mathrm{F}$.

2011 Outsourcing the Womb: Race, Class, and Gestational Surrogacy in a Global Market. Framing 21st

Century Social Issues series. New York: Routledge.

Unisa, S.

1999 Childlessness in Andhra Pradesh, India: Treatment Seeking and Consequences.

Reproductive Health Matters 7(13):54-64.

United Kingdom Office for National Statistics. Theme: Population

2014).

http://ons.gov.uk/ons/taxonomy/index.html?nscl=Population (accessed 8 December

Unnithan, M.

2013 Thinking through Surrogacy Legislation in India: Reflections on Relational

Consent and the Rights

of Infertile Women. Journal of Legal Anthropology 1(3):287-313.

Unnithan-Kumar, $\mathrm{M}$.

This article is protected by copyright. All rights reserved. 
2010 Female Selective Abortion-Beyond 'Culture': Family Making and Gender Inequality in a

Globalizing India. Culture, Health, \& Sexuality 12(2):153-166.

Vatuk,

2009 A Rallying Cry for Muslim Personal Law: The Shah Bano Case and Its Aftermath. In Islam

in South Asia in Practice, edited by Barbara Daly Metcalf, p. 352-70. Princeton:

Princeton University

Press.

Vlassoff, Carol

Studies 44(1):4-20.

1990 The Value of Sons in an Indian Village: How Widows See it. Population

2013 Gender Equality and Inequality in Rural India: Blessed with a Son. New York:

Palgrave

Vora, K.

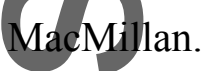

2012 Limits of "Labor": Accounting for Affect and the Biological in Transnational Surrogacy and Widge, A

Service Work. South Atlantic Quarterly 111(4):681-700.

In Current

2001 Sociocultural Attitudes Towards Infertility and Assisted Reproduction in India.

Practices and Controversies in Assisted Reproduction: Report of a WHO Meeting on Medical, Ethical and Social Aspects of Assisted Reproduction. World Health Organization, auth. and ed. Pp. 60-74.

Geneva: World Health Organization.

2005 Seeking Conception: Experiences of Urban Indian Women with In Vitro

Fertilization. Patient

Education and Counseling 59(3):225-233.

Williams, R. V.

2006 Postcolonial Politics and Personal Laws: Colonial Legal Legacies and the Indian

State. New Delhi:

Oxford University Press.

World Bank Fertility Rate, Total (Births per Woman)

http://data.worldbank.org/indicator/SP.DYN.TFRT.IN?page $=6$ (accessed 15 July

2015).

World Bank Land Area (sq. km.) http://data.worldbank.org/indicator/AG.LND.TOTL.K2 (accessed 8

December 2014).

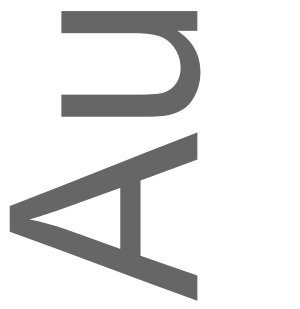

